\title{
Bilateral Deafness
}

National Cancer Institute

\section{Source}

National Cancer Institute. Bilateral Deafness. NCI Thesaurus. Code C36193.

Partial or total inability to hear sounds in both ears. 